\title{
Problems Existing in Financial Management in Tibetan Listed Companies and Countermeasures
}

\author{
Zhao Li, Gou Xiaojiang \\ Xizang Minzu University, Xianyang, Shaanxi Province, 712082 \\ 54892713@163.com
}

\begin{abstract}
Keywords: Listed companies in Tibet; Financial management; Working capital, Sustainable development
\end{abstract}

\begin{abstract}
Financial management, an indispensable part in enterprise management, should be given the top priority in the organization of the whole enterprise as it is the source for an enterprise's survival. Based on the information disclosed by listed companies in Tibet, this paper focuses on analyzing the financing mode, dividend distribution and working capital management of the listed companies in Tibet, so as to identify the problems and put forward suggestions for improvement. Thus, it is expected to optimize the financial management system and improve the level of financial governance for listed companies in Tibet, so that certain companies can achieve the sustainable development.
\end{abstract}

\section{Introduction}

In the establishment of modern system for enterprise management with the purpose of achieving sustainable development and ensuring the maximization of enterprise value, scientific and effective financial management can not neglected. Financial management, both a relatively independent part in business management and a comprehensive management work, is an indispensable part in business management. Financial management is the highest level in the organization of the whole enterprise, and it is the source for an enterprise's survival. Based on the information disclosed by listed companies in Tibet, this paper focuses on analyzing the financing mode, dividend distribution and working capital management of the listed companies in Tibet, so as to identify the problems and put forward suggestions for improvement. Thus, it is expected to optimize the financial management system and improve the level of financial governance for listed companies in Tibet, so that certain companies can achieve the sustainable development.

\section{The status quo of financial management in Tibetan listed companies}

Unitary financing structure and not standardized utilization of capital is not conducive to governance and growth of a company. After analyzing the annual financial report from 2008 to 2013 of 10 listed companies in Tibet, I find that the financing structure of the listed companies in Tibet is relatively unitary. The majority of listed companies mainly depend on financing by the newly issued stocks and refinancing by taking use of stock market is rare; through the financial statements analyzed, the long-term liability ratio is relatively low among listed companies in Tibet on the whole and some listed companies without long-term debt mainly finance through short-term debt. As can be seen, listed companies in Tibet show obvious preference for equity financing and its financing structure is relatively unitary. In addition, through the analysis of the information disclosed by the listed companies in Tibet, I find that some of the listed companies do not invest in the corresponding project as per agreement in the prospectus strictly. Through financing by the methods of stocks issuing, share allotment, and refinancing by additional stock, these enterprises not only do not advance in development, but also has the problems of deviated purpose for capital used for financing and low efficiency. Unitary financing structure and not standardized utilization of capital are not conducive to governance and growth of a company. 
High concentration of equity and invalid external supervisory mechanisms.

Table1 Status of Equity in Tibetan Listed Companies 2013

\begin{tabular}{|c|c|c|c|c|}
\hline Securities & $\begin{array}{c}\text { Proportion of } \\
\text { shares held by the } \\
\text { first-largest } \\
\text { shareholders (\%) }\end{array}$ & $\begin{array}{c}\text { Proportion of shares } \\
\text { held by the first-largest } \\
\text { and second-largest } \\
\text { shareholders (\%) }\end{array}$ & Index Z & Index S \\
\hline Meihua Group & 27.48 & 47.45 & 2.3122 & 40.11 \\
\hline Tibetan Tourism & 16.72 & 26.11 & 2.1418 & 14.42 \\
\hline Tibetan City Development Investment & 56.05 & 63.99 & 8.9471 & 11.47 \\
\hline Tibetan City Development & 10.65 & 20.58 & 1.1593 & 11.81 \\
\hline Tibetan Mining & 17.69 & 24.52 & 4.6834 & 11.48 \\
\hline Tibetan Pharmaceutical & 21.62 & 43.71 & 1.1677 & 37.46 \\
\hline Tibetan Qomolangma & 29.44 & 34.25 & 10.1072 & 8.71 \\
\hline Tibetan Tianlu & 27.58 & 35.11 & 3.8817 & 9.10 \\
\hline Qizheng Tibetan Pharmaceutical & 69.22 & 90.76 & 3.3478 & 22.70 \\
\hline Haisco Pharmaceutical Group & 40.33 & 63.26 & 1.7588 & 47.75 \\
\hline
\end{tabular}

As of the end of 2013, the situation of equity concentration for 10 listed companies in Tibet is shown in the table. Among them, the index $\mathrm{Z}$, the ratio of the number of shares held by the top shareholders and that of the second largest shareholders, is used to measure the impact of the second largest shareholders on the listed company; index S refers to the total proportion of shares held by all the tradable shareholders from the send largest one to the tenth largest one. We can see from the above table the first largest shareholder's share is significantly higher in the listed companies in Tibet. For instance, the proportion in both Tibetan City Development Investment and Qizheng Tibet Pharmaceutical surpasses 50\%, the proportion in Haisco Pharmaceutical Group surpasses over $40 \%$ and the proportion in other four surpasses $20 \%$. The proportion held by both the first largest and the second largest shareholder all surpass 20\% while the proportion in Qizheng Tibet Pharmaceutical reaches more than 90\%; In addition, it can be seen that $70 \%$ of the company have a higher index $\mathrm{Z}$ and unreasonable index $\mathrm{S}$, which shows that equity in Tibetan listed companies is concentrated and the dominance of one shareholder exists. The above-mentioned phenomenon shows that the supervision and control for the first largest shareholder in Tibetan listed companies is weak and there are defects existing in supervisory mechanism.

The lack of stability and continuity of dividend policy makes difference to the healthy and sustainable development of listed companies. Through analyzing the status quo of dividend distribution for 10 listed companies in Tibet and their annual report, despite the different influence degree of the specific characteristics for securities market and listed companies in China, they have a lot in common on the problems existed in the policy of dividend distribution. First of all, it is shown by the lack of necessary institutional constraints and norms in dividend distribution. In dividend distribution, the following disadvantages exist: the characteristics of random, the variability of distribution, the phenomenon of no distribution and lack of continuity. Secondly, it is shown by the fact that the cash dividend is treated as the main form in dividend distribution. In the cash dividend, dividend per share is greater than earnings per share and the gap is filled up by balances of the past years. Moreover, the situation dividend in cash surpasses the cash flow. The dividend is not only low, but also for certain period, which is the ultra-ability dividends payout. Such casual and instable distribution policy for dividend, known as ultra-ability dividends payout which lacks continuity, is likely to lead to financial distress for the lack of liquidity, which would affect a company's healthy and sustainable development.

The lack of scientific management for working capital. Working capital can be used to measure and evaluate the short-term solvency of an enterprise. The greater the number of working capital for a company, the stronger its short-term solvency will be. It shows the company's full preparation for bearing the obligation of payment. When working capital of an enterprise is negative, current assets less than current liabilities, it means that normal operation of the company may be interrupted at any time because of ineffective capital turnover. Therefore, to maintain the 
normal operation of an enterprise, it is necessary to possess a proper amount of working capital. However, the amount of working capital maintained is the key to decision-making. If a company's working capital is too large and its liquidity is too strong, it shows that asset utilization of the enterprise is not high; if the working capital of the enterprise is too small and its liquidity is too weak, it shows that problems exist in current assets of the enterprise and it has a greater pressure on clearing debt. The basic principle for scientific and reasonable working capital management refers to the one that can not only satisfy capital demand for the normal operation of an enterprise, with high efficiency in the use of funds and lower cost, but also to maintain adequate short-term debt paying ability. Under normal circumstances, the index for working capital management should maintain certain stability. However, through analysis in the following table, the fluctuation of annual index is sharp and discontinuous, which shows that production and management activities of an enterprise is not stable and it lacks policy and index for regular management of working capital. To certain degree, it illustrates mess operation and management for overall capability of an enterprise and further affects its sustainable development.

\begin{tabular}{|c|c|c|c|c|c|c|}
\hline Index/Time & 2008 & 2009 & 2010 & 2011 & 2012 & 2013 \\
\hline $\begin{array}{c}\text { Turnover Rate } \\
\text { of Accounts } \\
\text { Receivable }\end{array}$ & 11.76578 & 3442.488 & 274.0709 & 131.1002 & 246.2238 & 146.331 \\
\hline $\begin{array}{c}\text { Turnover Rate } \\
\text { of Stock }\end{array}$ & 2.825215 & 56.44233 & 69.5017 & 36.0332 & 179.444 & 2608.195 \\
\hline $\begin{array}{c}\text { Turnover Rate } \\
\text { of Total Capital }\end{array}$ & 0.182996 & 0.330243 & 0.298708 & 0.401392 & 0.356536 & 0.355414 \\
\hline
\end{tabular}

\section{Suggestions on improvement}

Financial strategic objectives of enterprises designed for the sustainable development of the listed companies in Tibet. The scientific and reasonable financial strategic goal is a basic premise to make the financial strategic plan for an enterprise and to carry out the financial strategy for an enterprise effectively. Listed companies in Tibet must break up the traditional idea and establish a harmonious financial relationship. In addition to creating wealth for as many shareholders as possible, the strategic objectives for financial management take into account environmental protection and social balanced development, so as to ensure the harmony and unification for economic target and social target of an enterprise and achieve win-win situation for both the enterprise and the society. At the same time of improving sales for products and service, as well as the rate of market share, we must keep maintaining long-term stable development of an enterprise as the principle and give top priority to an enterprise's long-term interests. At the same time of pursuing profit, we'd focus on environmental protection and increase employment opportunities for the society as far as possible, so as to actively build a harmonious society and realize the enterprise's sustainable development.

With "people-oriented" as the ideal, strengthen constructing the team of financial management and improve the level of financial management. According to the information on relevant person in charge provided in the annual report of 10 listed companies Tibet in 2013, four people majors in the profession as explicitly mentioned. Among them, 2 are undergraduates and 2 are masters; other financial personnel are not mentioned whether they major in the profession of financial management or not. Obviously, the Tibetan listed companies lack badly financial management personnel with comprehensive quality. Therefore, Tibetan listed companies should consciously strengthen constructing the personnel team of financial management, and improve basic professional quality of financial personnel through continuing education, mutual communication and talent introduction. Based on developing the basic business quality of financial management personnel, we'd emphasize the consciousness of management, innovation, the sense of responsibility and building healthy atmosphere. Besides, we'd adhere to both the constraints of 
regulatory system and financial policies, so as to give full play to the effect and efficiency of financial management and improve the level of financial management.

Optimize the capital structure of listed companies, so as to promote the innovation of financial management and improve the efficiency of financial governance. Currently capital structure of listed companies in Tibet is not so reasonable and equality is highly concentrated. As the index $\mathrm{Z}$ is too high, the supervision and restraint mechanisms of the second largest shareholder for the first major shareholders is relatively weak and due constraints and supervision fails to take effect. Listed companies in Tibet shall optimize the company's capital structure and improve the equity structure, so as to improve performance and value of the company. From the perspective constraining the big shareholders to occupy interests of small shareholders, companies with dispersed equity have better performance. Besides, at the same time of reducing state-owned shares gradually, we'd encourage investors and banks to hold centralized stock ownership, so as to be the active shareholders of an enterprise. Thus, supervise and prevent internal personnel from holding down the cost of equity capital.

At the same time, listed companies in Tibet should actively promote the innovation of financial management, and comprehensively improve the level of financial management. For example, we should ensure the timely recovery of accounts receivable and the stable flow of sales channel, so as to fully improve the rate of return on capital; when granting a loan, we'd choose the right bank to lower the cost of capital; in investment, we'd strengthen relevant work on argumentation and do well the job on prediction and controlling; strengthen relevant management on bills, such as exchange bills, so as to improve the turnover speed of bills; we can also use online banking to make settlement on capital, so as to improve the speed of capital settlement.

Improve the internal control system on financial affairs, so as to establish evaluation system for financial management strategy with sustainable development as the orientation. Scientific and reasonable financial management can greatly improve the efficiency for the use of financial resources, while the internal control system of financial affairs can effectively prevent and resolve the internal risks encountered in the process for the operation of a business. In the process of establishing internal control system of financial affairs, we'd design reasonable and simple method for control, which should be not tedious and in line with the actual situation of an enterprise, on the basis of conscientious summary and scientific analysis; we'd have the purpose that the system can do prior prevention and identify vulnerability at the time during and after the process; at the same time, the system shall have the function of preventing mistakes and promoting the effect of management; listed companies in Tibet should establish scientific and effective internal control system accordingly according to the characteristics of respective enterprises, so that clearly define and implement the division of responsibilities, processing procedures and processes. In addition, listed companies in Tibet should also attach importance to the selection and training of personnel on management for internal control system, so as to strengthen the function of accounting control system and give full play to the role of internal audit institutions. Besides, we'd establish and improve the mechanism on dynamic analysis and prediction, so as to enhance the ability of risk identification for certain enterprise. Moreover, the comprehensive budget system should be actively implemented in order to reduce the financial risks.

Evaluation on financial strategy, which is an important basis for adjusting, continuously operating, restructuring or ending a financial strategy, is an important link in the process of financial strategy operation. Due to different industries and different life cycles in the same industry, as well as the difference in development strategy, especially financial strategy, listed companies in Tibet shall establish evaluation system on financial strategy with sustainable development as the orientation, so as to make effective judgment for the effect after execution and achieve the combination between strategy and operation.

\section{Acknowledgements}

Topic: Number of humanities and social sciences project in Tibet college in2015: sk2015--65 


\section{Reference}

[1] Peng Yan. On the Importance of Financial Management to Enterprise Management [J]. Foreign Entrepreneurs.2015 (25)

[2] Yao Song. On the Role of Financial Management in the Enterprise [J]. Market Modernization.2014 (27)

[3] Zhao Lianwei. Exploration on How to Improve the Financial Management Level of an Enterprise [J]. Money China (Academic Edition).2015 (22)

[4] Sun Yong. Problems Exist in Financial Management of an Enterprise and Countermeasures [J]. Modern Economic Information.2015 (19) 